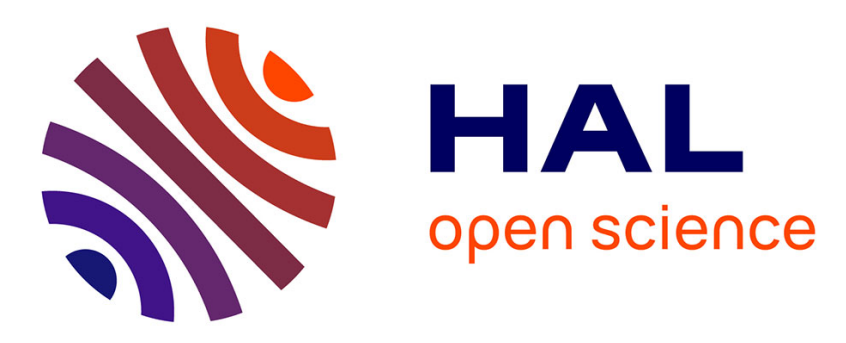

\title{
Thermochronological evidence for Mio-Pliocene late orogenic extension in the north-eastern Albanides
} (Albania)

Bardhyl Muceku, Pieter van Der Beek, Matthias Bernet, Peter Reiners, Georges Mascle, Artan Tashko

\section{To cite this version:}

Bardhyl Muceku, Pieter van Der Beek, Matthias Bernet, Peter Reiners, Georges Mascle, et al.. Thermochronological evidence for Mio-Pliocene late orogenic extension in the north-eastern Albanides (Albania). Terra Nova, 2008, 20 (3), pp.180-187. 10.1111/j.1365-3121.2008.00803.x . hal-00286529

\section{HAL Id: hal-00286529 \\ https://hal.science/hal-00286529}

Submitted on 9 Jun 2008

HAL is a multi-disciplinary open access archive for the deposit and dissemination of scientific research documents, whether they are published or not. The documents may come from teaching and research institutions in France or abroad, or from public or private research centers.
L'archive ouverte pluridisciplinaire HAL, est destinée au dépôt et à la diffusion de documents scientifiques de niveau recherche, publiés ou non, émanant des établissements d'enseignement et de recherche français ou étrangers, des laboratoires publics ou privés. 


\title{
Thermochronological evidence for Mio-Pliocene late orogenic extension in the north-eastern Albanides (Albania)
}

\author{
Bardhyl Muceku ${ }^{\left(1,2^{*}\right)}$, Peter van der Beek, ${ }^{(1)}$ Matthias Bernet $^{(1)}$, Peter \\ Reiners $^{(3)}$, Georges Mascle ${ }^{(1)}$, and Artan Tashko( ${ }^{(2)}$ \\ ${ }^{1}$ Laboratoire de Géodynamique des Chaînes Alpines, Université Joseph Fourier, BP 53, \\ 38041 Grenoble, France. \\ 2 Faculty of Geology and Mining, Polytechnic University of Tirana, Rruga Elbasani, Tirana, \\ Albania. \\ ${ }^{3}$ Department of Geosciences, University of Arizona, Tucson, AZ 85721, USA. \\ *corresponding author, email: bmuceku@ujf-grenoble.fr
}

Running title: late orogenic extension in the NE Albanides

\begin{abstract}
New apatite and zircon (U-Th)/He and apatite fission-track data allow constraining the timing of Miocene-Pliocene extensional exhumation that affected the central part of the Dinarides-Albanides-Hellenides orogen. Apatite (U-Th)/He ages in the northern and western Internal Albanides range from $57 \mathrm{Ma}$ to $17 \mathrm{Ma}$, contrasting to younger ages of 5.2 to 9.3 Ma in the eastern Internal Albanides. Eastward younging is also reflected in zircon $(\mathrm{U}-\mathrm{Th}) / \mathrm{He}$ ages varying from $101 \mathrm{Ma}$ in the north-western Internal Albanides to 19-50 Ma in the east, as well as in recently published apatite fission-track ages. Thermal history predictions with the new data point to a phase of rapid exhumation of the eastern Internal Albanides around 6-4 Ma, while the western Internal Albanides record slower continuous
\end{abstract}


exhumation since the Eocene. This asymmetric exhumation pattern is most likely linked to extensional reactivation of NE-SW trending thrusts east of the Mirdita zone and within the Korabi zone of the eastern Internal Albanides.

Keywords: Albanides, exhumation, extension, fission-track, (U-Th)/He

\section{INTRODUCTION}

1. The eastern Mediterranean Dinarides-Albanides-Hellenides orogen (Fig. 1) formed by subduction of Adriatic continental lithosphere beneath the Eurasian plate since the EoceneOligocene. Neogene extension has been extensively studied within this orogen and the Aegean region in general, (e.g., Gautier and Brun, 1994; Jolivet and Patriat, 1999), and Neogene extensional basins have been described in Macedonia (e.g., Dumurdzanov et al., 2005) and southern Albania (e.g., Tagari et al., 1993). Extension has as yet not been characterized in detail further north, in the northern Albanides and Dinarides. Even though late orogenic extension is a widespread phenomenon in the Mediterranean convergence zone (e.g., Jolivet and Facenna, 2000), the underlying processes are discussed controversially in the literature, and have been attributed to either extensional collapse (e.g., Dewey, 1988), slab roll-back (Royden 1993; Jolivet and Facenna, 2000), or slab detachment (Wortel and Spakman, 2000). Extensional faulting permits rapid tectonic exhumation that can be recorded with low-temperature thermochronology (e.g., Foster and John, 1999; Brichau et al., 2006). Here, we document late orogenic exhumation in the northern Albanides using (U-Th)/He and fission-track (FT) thermochronology, which allows establishing the timing and rate of extensional exhumation in the eastern Internal Albanides.

2. The Albanides form the central part of the Dinarides-Albanides-Hellenides orogen (Figs. 1 and 2) and are characterized by three fundamental components: a western fold-and- 
thrust belt (External Albanides), a Central Belt characterized by the occurrence of ophiolitic nappes (Mirdita zone), and an eastern continental Internal Complex (Gashi, Korabi and Rubiku zones) (e.g., Robertson and Shallo, 2000; Meço and Aliaj, 2000; Cavazza et al., 2004;

Muceku et al., 2006). The ophiolitic nappes of the Central Belt were obducted onto the Internal Complex during the mid-Jurassic (Dimo-Lahitte et al., 2001), and the whole structure was thrust westward during Eocene-Oligocene times, when the Adriatic margin began subducting below the European margin (Fig. 3). The evolution of the fold-and-thrust belt in the external Albanides is well known, as it has been the target of extensive petroleum exploration (Frasheri et al., 1996; Meço and Aliaj, 2000; Robertson and Shallo, 2000; Cavazza et al., 2004; Roure et al., 2004). In contrast, the recent evolution of the Central Belt and the Internal Complex, together known as the Internal Albanides, has received much less attention. Recently published apatite and zircon FT data from the Internal Albanides show that the eastern part of the orogen experienced apparently rapid cooling and exhumation since the late Pliocene, whereas the western Internal Albanides show much slower exhumation throughout the Cenozoic (Muceku et al., 2006). However, this exhumation history was based on thermal modeling of apatite fission-track (AFT) data alone. Here, we provide an improved reconstruction using new apatite and zircon $(\mathrm{U}-\mathrm{Th}) / \mathrm{He}$ and AFT ages from the Internal Albanides, in order to better constrain the cooling and exhumation history. We also discuss the tectonic implications of observed contrasting exhumation histories.

\section{PRESENT-DAY STRUCTURE AND DEFORMATION OF THE ALBANIDES}

3. Geological and geophysical data indicate eastward thickening of the Albanian crust from about $30 \mathrm{~km}$ in western Albania to $45-50 \mathrm{~km}$ near the Macedonian and Greek borders (Fig. 3; Frasheri et al., 1996; Papazachos et al., 2002; Cavazza et al., 2004). Seismological studies have identified a gently eastward-dipping slab below the Dinaric-Hellenic belt, with 
compressional focal mechanisms in the western Albanides, and extensional focal mechanisms in the eastern Albanides (Aliaj, 1991; Muço, 1994; Frasheri et al., 1996; Louvari et al., 2001). Present-day stress indicators in the Dinaric-Hellenic belt also point toward a NE-SW oriented compressional stress field in the external zones, and tensional stress in the internal zones of the Albanides (e.g., Mariucci and Müller, 2003). Global plate motion vectors are compatible with the existence of a Dinaric compressive boundary (De Mets et al., 1990; Sella et al., 2002). GPS data show a NE oriented displacement of the external Dinaric units at a velocity of $5 \mathrm{~mm} / \mathrm{yr}$ with respect to stable Europe, while the internal Dinaric units move slightly faster in the same direction (McKlusky et al., 2000; Khale et al., 2000; Anzidei et al., 2001; Hollenstein et al., 2003). Therefore, all these data suggest the existence of a compressional regime in the western belt, related to subduction of the Adriatic lithosphere, and a tensional regime in the eastern belt.

\section{THERMOCHRONOLOGICAL RESULTS}

4. Fission-track and (U-Th)/He analyses of apatite and zircon are commonly used for dating the low-temperature evolution and exhumation of upper crustal rocks. Using multiple thermochronometer analysis on the same or nearby samples allows constraining detailed cooling paths between closure of the zircon fission-track (ZFT) system at $\sim 240^{\circ} \mathrm{C}$ (Brandon et al., 1998) down to the closure temperature for the apatite (U-Th)/He (AHe) system at $65-85$ ${ }^{\circ} \mathrm{C}$ (Wolf et al., 1996; Farley, 2000). Newly developed numerical modeling tools (Ketcham, 2005) allow combined inversion of AHe, AFT and zircon (U-Th)/He (ZHe) data to quantify these cooling paths.

5. The eight Helium and three new AFT ages presented in this study are summarized

in Tables 1 and 2 respectively, and shown in Figure 2. AHe ages show a strong eastward decrease, from $\sim 57 \mathrm{Ma}$ in the Mirdita zone (sample AM4-02) to $\sim 17 \mathrm{Ma}$ in the Gashi zone 
(AM15-00) and $\sim 5 \mathrm{Ma}$ in the eastern Korabi zone (AM26-03, AM20-00). This eastward decrease is consistent with recent AFT results (Muceku et al., 2006) and also shows up in the ZHe ages, which are $\sim 101 \mathrm{Ma}$ in the Gashi zone (AM15-00), 50 Ma in the western Korabi (AM08-00) and $\sim 20 \mathrm{Ma}$ in the eastern Korabi (AM26-03). These new data emphasize the significant differences in cooling histories between rocks of the Gashi zone in the north, the western part of the Mirdita zone, and the Korabi zone in the east of the Internal Albanides as previously inferred by Muceku et al. (2006) (Fig. 3).

\section{DISCUSSION}

6. The new AHe, AFT, and ZHe data, combined with previously published AFT and ZFT ages, allow constraining the cooling and exhumation history of the Internal Albanides in detail. We dated samples AM4-02, AM15-00, AM20-00 and AM26-03 with at least two thermochronologic systems and will use these to quantify cooling paths for the Mirdita, Gashi and Korabi zones, respectively (Fig. 4).

\section{Northern and western Internal Albanides}

7. Ophiolitic rocks of the western Mirdita zone (Sample AM4-02, Fig. 4a) are marked by a phase of relatively fast cooling $\left(\sim 9^{\circ} \mathrm{C} / \mathrm{Myr}\right)$ during the latest Cretaceous, and much slower cooling $\left(\sim 1-2^{\circ} \mathrm{C} / \mathrm{Myr}\right)$ ever since, implying that long-term exhumation rates were relatively slow $(\sim 0.1 \mathrm{~mm} / \mathrm{yr})$ in this area throughout the Cenozoic. ZHe, AFT and AHe ages obtained from the Gashi zone in northern Albania (Sample AM15-00, Fig. 4b) also suggest overall slow long-term cooling, starting at a rate of $\leq 1{ }^{\circ} \mathrm{C} / \mathrm{Myr}$ in the mid-Cretaceous, and increasing to $\sim 3-4{ }^{\circ} \mathrm{C} / \mathrm{Myr}$ between $\sim 30$ and $\sim 10 \mathrm{Ma}$. 


\section{Eastern Internal Albanides}

8. In the eastern part of the Internal Albanides, the new (U-Th)/He data are in good agreement with recent AFT results. The youngest AFT, ZHe and AHe ages are measured in sample AM26-03 from the Korabi zone, in the eastern hangingwall of the Peshkopia Tectonic Window (3 km from the contact; Figs. 2 and 3), where Triassic evaporites and Oligocene flysch of the external Albanides are exposed below the overriding metamorphic internal units. The ZHe age of $\sim 20 \mathrm{Ma}$ obtained in this sample is much younger then nearby ZFT ages of 125 to $156 \mathrm{Ma}$ (Muceku et al., 2006), implying very slow rates of cooling $\left(<1^{\circ} \mathrm{C} / \mathrm{My}\right)$ prior to $\sim 20 \mathrm{Ma}$. The thermal history of this sample (Fig. 4d) records relatively slow cooling of 1-8 ${ }^{\circ} \mathrm{C} / \mathrm{My}$ between 20 and $6 \mathrm{Ma}$, followed by a pulse of rapid cooling at $30^{\circ} \mathrm{C} / \mathrm{My}$ from about 6 to $4 \mathrm{Ma}$ in the eastern Internal Albanides. This rate is much faster than any cooling rate observed in other regions of the Internal Albanides. It is confirmed by analysis of a nearby sample from the eastern Korabi zone (AM20-00, Fig. 4c) for which AFT and AHe ages, together with apatite fission-track length data are available, and which shows a similar cooling history. Our thermochronologic data are thus consistent with the existence of a tectonic window in the Korabi zone (Fig. 2), as postulated by Collaku et al. (1990) and Melo et al. (1991), and suggest the timing of final exhumation of this window to be late Miocene early Pliocene in age.

9. In order to quantify the amount of exhumation associated with rapid cooling of the eastern Korabi zone, we use a transient 1D thermal model (Heat1D; Braun et al., 2006) to forward model the cooling paths, based on an undisturbed thermal gradient for this region of $25^{\circ} \mathrm{C} / \mathrm{km}$ (Cermak et al., 1996). Best-fit histories are characterized by long-term exhumation rates of $\sim 0.16 \mathrm{~mm} / \mathrm{y}$, with a pulse of exhumation at $1.2 \mathrm{~mm} / \mathrm{y}$ between 6 and $4 \mathrm{Ma}$ (Fig. $4 \mathrm{~d}$ ). This pulse results in a transient increase in near-surface geothermal gradients of $\sim 10 \%$. Thus, 
final exhumation of the eastern Korabi zone during the 6 - 4 Ma rapid cooling phase amounted to $\sim 2.4 \mathrm{~km}$.

\section{Tectonic implications}

10. Rapid exhumation in the Korabi zone between $6-4$ Ma contrasts strongly with continuous slow exhumation further west and north in the internal Albanides. Such a localized phase of rapid exhumation can be explained either by localized erosion, by tectonic exhumation, or by a combination of both. Discriminating between the two end-member scenarios (erosion vs. tectonic exhumation) requires comparing the calculated exhumation rates with sediment volumes derived from the internal Albanides (e.g., Kuhlemann et al., 2001). The erosional products of the internal Albanides are exported toward the external Albanian wedge-top / foreland basin (e.g. Roure et al., 2004), as well as to the Adriatic Sea (Figs. 2 and 3). However, no detailed studies on the sediment budgets for these basins are currently available. However, the strong lateral gradient in rock uplift rates implied by the thermochronologic data suggests accommodation of this variation by faulting. The presentday structure of the Albanides, with major west-dipping faults forming the boundary between the Mirdita and Korabi zones and occurring within the Korabi zone constrains such faulting to be extensional on reactivated NE-SW trending former thrust fault systems (Fig. 2 and 3). Kilias et al. (2001) report a transition from regional compression to extension at the MioPliocene boundary in the Albanides, consistent with the timing of rapid exhumation reported here. Even if our samples were collected with the purpose to gain a regional overview, and are not related to specific individual faults, they reflect differential cooling between major fault systems (Fig. 2).

11. We thus suggest that late Oligocene to early Miocene crustal thickening and shortening in the Albanides changed to an extensional regime in the eastern part of the orogen 
at about $6 \mathrm{Ma}$. This interpretation is in good agreement with the tectonic evolution of the Albanides documented in Macedonia (Dumurdzanov et al., 2005), where renewed extension is recorded to migrate westward since Neogene times. Furthermore, the youngest extensional basins in western Macedonia and eastern Albania initiated during the Pliocene (Dumurdzanov et al., 2005; Tagari et al., 1993). This extensional phase has been linked both to rollback of a continuous slab under the Albanides (Royden, 1993; Dumurdzanov et al., 2005) and to a southward propagating tear in the Adriatic subducting slab (Wortel and Spakman, 2000), leading to localized uplift and extension in the overriding plate (e.g., Buiter et al., 2002). Our thermochronological data do not allow discriminating between these competing hypotheses, but they indicate that rocks of the Korabi zone where exhumed from 2-3 km depth during this late extension phase.

\section{CONCLUSIONS}

12. The application of $(\mathrm{U}-\mathrm{Th}) / \mathrm{He}$ and FT thermochronology helps to better understand the cooling and exhumation history of the Internal Albanides. Slow cooling and exhumation $(<0.1 \mathrm{~mm} / \mathrm{y})$ of the northern and western Internal Albanides since Late Eocene-Early Oligocene times is likely a response to crustal thickening near the frontal thrust during tectonic emplacement of the internal units on top of the external fold-and-thrust belt. We propose that the present-day symmetric structure of the ophiolite units in the Internal Albanides is a result of Miocene-Pliocene extension on reactivated former thrust faults, affecting the eastern ophiolites and the Korabi zone. (U-Th)/He and AFT data allow determining the beginning of this extensional phase at less than 20 Ma. Exhumation of the Korabi zone rocks accelerated at 6-4 Ma, reaching a rate of about $1.2 \mathrm{~mm} / \mathrm{y}$ during this time. These results are in good agreement with regional structural and stratigraphic information. 


\section{ACKNOWLEDGEMENTS}

13. Apatite and zircon (U-Th)/He analyses for this study were performed during and supported by the Helium Dating Workshop at Yale (HeDWaY) 2005. We thank John Garver and Çerçis Durmishi for discussions and S. Nicolescu for analytical help. BM was supported by a PhD grant from the French Ministry of Foreign Affairs and the NATO Science for Peace program. We gratefully acknowledge critical but constructive reviews by the associate editor and two anonymous reviewers, which helped to improve the manuscript. 


\section{REFERENCES}

Aliaj S. 1991. Neotectonic structure of Albania. Albanian Journal on Natural and Technological Science, 4, 79-98.

Anzidei M., Baldi P., Casula G., Galvani A., Mantovani E., Peci A., Riguzzi F. and Serpelloni E. 2001. Insights into present-day crustal motion in the central Mediterranean area from GPS surveys. Geophysical Journal International, 146, 98-110.

Brandon M.T., Roden-Tice M.R. and Garver J.I. 1998. Late Cenozoic exhumation of the Cascadia accretionary wedge in the Olympic Mountains, northwest Washington State. Geological Society of America Bulletin, 100, 985-1009.

Brichau S., Ring U., Ketcham R., Carter A., Stockli D. and Brunel M. 2006. Constraining the longterm evolution of the slip rate for a major extensional fault system in central Aegean, Greece, using thermochronology. Earth and Planetary Science Letters, 241, 293-306.

Braun, J., van der Beek, P. and Batt, G., 2006. Quantitative Thermochronology: Numerical Methods for the Interpretation of Thermochronological Data. Cambridge University Press, Cambridge, New York.

Buiter, S. J. H., Govers, R., and Wortel, M. J. R. 2002. Two-dimensional simulations of surface deformation caused by slab detachment. Tectonophysics, 354, 195-210.

Carlson W.D., Donelick R.A. \& Ketcham R.A. 1999. Variability of apatite fission track annealing kinetics I: Experimental results. American Mineralogist, 84, 1213-1223.

Cavazza W., Roure F.M., Spakman W., Stampfli G.M. and Ziegler P.A (Eds.) 2004. The TRANSMED atlas - The Mediterranean Region from Crust to Mantle. Springer, $141 \mathrm{p}$.

Cermak V., Kresl M., Kucerova L., Safanda J., Frasheri A., Kapedani N., Lico R., \& Cano D. 1996. Heat flow in Albania. Geothermics, 25, 91-102. 
Collaku A., Cadet J.P., Melo V. \& Bonneau M. 1990. Sur l'allochtonie des unités Albanaises : mise en évidence de fenêtres tectoniques à l'arrière de la nappe ophiolitique de la Mirdita (Albanie). Comptes Rendus de l'Académie des Sciences de Paris, 311, 1251-1258.

DeMets C., Gordon R.G., Argus D.F. and Stein S. 1990. Current plate motions. Geophysical Journal International, 101, 425-478.

Dewey J. F. 1988. Extensional collapse of orogens. Tectonics, 7, 1123 - 1139.

Dimo-Lahitte A., Monié P. and Vergely P. 2001. Metamorphic soles from the Albanian ophiolites : petrology, ${ }^{40} \mathrm{Ar}-{ }^{39} \mathrm{Ar}$ geochronology, and geodynamic evolution. Tectonics, 20, 78-96.

Donelick, R.A., Ketcham, R.A., \& Carlson, W.D. 1999. Variability of apatite fission-track annealing kinetics: II Crystallographic orientation effects. American Mineralogist, 84, 12241234.

Dumurdzanov N., Serafimovski B. T. and Burchfiel C. 2005. Cenozoic tectonics of Macedonia and its relation to the South Balkan extensional regime. Geosphere, 1, 1-22, doi: 10.1130/GES00006.1

Farley, K. A. 2000. Helium diffusion from apatite: General behavior as illustrated by Durango fluorapatite. Journal of Geophysical Research, 105, 2903-2914.

Frasheri A., Nishani P., Bushati S. and Hyseni A. 1996. Relationship between tectonic zone of the Albanides, based on results of geophysical studies. In: Ziegler P. and Horvath F. (eds), PeriTethys Memoir 2: Structure and Prospects of Alpine Basins and Forelands, Mem. Museum Hist. Nat. Paris, 170, 485-511.

Foster, D. A. \& John, B. E. 1999. Quantifying tectonic exhumation in an extensional orogen with thermochronology: examples from the southern Basin and Range Province. In: Ring, U., Brandon, M.T., Lister, G. S. \& Willett, S. D. (eds) Exumation Processes: Normal Faulting, Ductile Flow and Erosion. Geological Society, London, Special Publication, 154, 343-364. 
Galbraith R.F. et Laslett G.M. 1993. Statistical models for mixed fission track ages. Nuclear Tracks, 21, 459- 470.

Gallagher K., Brown R. and Johnson C. 1998. Fision track analysis and its applications to geological problems. Annual Review of Earth and Planetary Sciences, 26, 519-572.

Gautier P. and Brun J.P. 1994. Crustal-scale geometry and kinematics of late-orogenic extension in the central Aegean (Cyclades and Ewia Island), Tectonophysics, 238, 399-424.

Hollenstein C., Khale H.G., Geiger A., Jenny S., Goes S. and Giardini D. 2003. New GPS constraints on the Africa-Eurasia plate motion boundary zone in southern Italy. Geophysical Research Letters, 30, 1935, doi : 10.1029/2003GL017554.

Jolivet L. and Faccenna C. 2000 Mediterranean extension and the Africa-Eurasia collision, Tectonics, 19, 1095-1106.

Jolivet L. and Patriat M. 1999 Ductile extension and the formation of the Aegean Sea, in Durand, B., Jolivet, L., Horvath, F. and Seranne, M., eds., The Mediterranean basins: Tertiary extension within the Alpine Orogen, Geological Society Special Publication, 156, 427-456.

Ketcham, R.A., 2005, Forward and Inverse Modeling of Low-Temperature Thermochronometry Data, in Reiners, P.W., and Ehlers, T.A., eds., Low-Temperature Thermochronology: Techniques, Interpretations, and Applications, Reviews in Mineralogy and Geochemistry, 58, 275-314.

Khale H.G., Cocard M., Peter Y., Geiger A., Reitlinger R., Barka A. and Veis G. 2000. GPSderived strain rate field within the boundary zones of the Eurasian, African and Arabian plates. Journal of Geophysical Research, 105, 23353-23370.

Kilias A., Tranos M., Mountrakis D., Shallo M., Marto A. \& Turku I. 2001. Geometry and kinematics of deformation in the Albanian orogenic belt during the Tertiary. Journal of Geodynamics, 31, 169-187. 
Kuhlemann J., Frisch W., Dunkl I. and Székely B. 2001. Quantifying tectonic versus erosive denudation by the sediment budget: the Miocene core complexes of the Alps. Tectonophysics, $330,1-23$.

Louvari E., Kiratzi A., Papazachos B. and Hatzidimitriou P. 2001. Fault-plane solutions determined by waveform modeling confirm tectonic collision in the Eastern Adriatic. Pure and Applied Geophysics, 158, 1613-1637.

Mariucci M.T. and Müller B. 2003. The tectonic regime in Italy infered from borehole breakout data. Tectonophysics, 361, 21-35.

McKlusky S., Balassanian S., Barka A., Demir C., Ergintav S., Georgiev I., Gurkan O., Hamburger M., Hurst K., Kahle H., Kastens K., Kekelidze G., King R., Kotzev V., Lenk O., Mahmoud S., Mishin A., Nadariya M., Ouzounis A., Paradissis D., Peter Y., Prilepin M., Reilinger R., Sanli I., Seeger H., Tealeb A., Toksöz M.N. and Veis G. 2000. Global Positioning System constraints on plate kinematics and dynamics in the Eastern Mediterranean and Caucasus. Journal of Geophysical Research, 105, 5695-5719.

Meço S. and Aliaj S. 2000. Geology of Albania. Beiträge zur Regionalen Geologie der Erde, Bd. 28, Borntraeger, $246 \mathrm{p}$.

Melo, V., Aliaj, Sh., Kodra, A., Xhomo, A., Lulo, P., Gjata, K. and Hoxha, V. 1991. Tectonic windows of the outer zones in the eastern regions of Albaniades: Geological Sciences Bulletin, 24-30 (in Albanian).

Muceku B., Mascle G and Tashko A. 2006. First results of fission-track thermochronology in the Albanides. In: Robertson, A. H. F. \& Mountrakis, D. (eds) Tectonic development of the Eastern Mediterranean Region. Geological Society Special Publication, 260, 539-556.

Muço B. 1994. Focal mechanism solutions for Albanian earthquakes for the years 1964-1988. Tectonophysics, 231, 311-323. 
Papazachos C., Scordilis E. and Peci V. 2002. P- \& S-deep velocity structure of the southern Adriatic-Eurasia collision obtained by robust non-linear inversion of travel times. $50^{\text {th }}$ ESC Assembly, Genoa, Extended Abstract, 8p.

Reiners P. W., Farley K. A., and Hickes H. J. 2002. He diffusion and (U-Th)/He thermochronometry of zircon: Initial results from Fish Canyon Tuff and Gold Butte: Tectonophysics, 349, 247-308.

Reiners P. W., Spell T. L., Nicolescu S. and Zanetti, K.A. 2004. Zircon (U-Th)/He thermochronometry: He diffusion and comparisons with ${ }^{40} \mathrm{Ar} /{ }^{39} \mathrm{Ar}$ dating, Geochimica et Cosmochimica Acta, 68, 1857-1887.

Robertson A. and Shallo M. 2000. Mesozoic-Tertiary evolution of Albania in its regional Eastern Mediterranean context. Tectonophysics, 316, 197-254.

Roure, F., Sh. Nazaj, K. Mushka, I. Fili, J.-P. Cadet, and M. Bonneau. 2004. Kinematic evolution and petroleum systems - An appraisal of the Outer Albanides, in K. R. McClay, ed., Thrust Tectonics and Hydrocarbon Systems, American Association of Petroleum Geologists Memoir $82,474-493$.

Royden, L.H. 1993. The tectonic expression slab pull at continental convergent boundaries, Tectonics, 12, 303-325.

Sella G.F., Dixon T.H. and Mao A. 2002. REVEL: a model for recent plate velocities from space geodesy. Journal of Geophysical Research, 107, 2081, doi :10.1029/2000JB000033.

SHGJSH (Geological Service of Albania). 2003. Geological map of Albania. Scale 1/200.000. $2^{\text {nd }}$ Edition, Tirana, Albania.

Tagari D., Vergely P. and Aliaj S. 1993. Tectonique polyphasée plio-quaternaire en Albanie orientale (région de Korça-Progradeci), Bulletin de la Société Géologique de France, 164, $727-737$ 
Wolf, R. A., Farley, K. A., and Silver, L. T., 1996, Helium diffusion and low-temperature thermochronometry of apatite. Geochimica et Cosmochimica Acta, 60, 4231-4240.

Wortel M.J.R. and Spakman W. 2000. Subduction and slab detachment in the MediterraneanCarpathian region. Science, 290, 1910-1917. 


\section{Figure Captions}

Fig. 1. Geodynamic setting of the Albanides in the Mediterranean context; map shows major tectonic units and present-day displacement vectors from GPS studies (after McKlusky et al., 2000; Khale et al., 2000; Anzidei et al., 2001; Hollenstein et al., 2003). Box indicates location of Figure 2.

Fig. 2. Schematic geological map of the Albanides (modified from SHGJSH, 2003) showing main structural provinces as well as recent (Muceku et al., 2006) and new thermochronological results. New data reported here are apatite and zircon (U-Th)/He ages shown in bold as well as three new apatite fission-track ages indicated by asterisks. Pz, Paleozoic; Pe, Permian; Mz, Mesozoic; Tr, Triassic; J, Jurassic; Cr, Cretaceous; Pg, Paleocene; Ng, Neocene; Q, Quaternary.

Fig. 3. A) Crustal cross-section of the Albanides (modified after Roure et al., 2004) and general cooling paths inferred from thermochronological data. Representative ages and closure temperatures are plotted for the different systems studied and three main regions; the Mirdita, Gashi and Korabi zones. Adopted closure temperatures are $240^{\circ} \mathrm{C}$ for the ZFT system (Brandon et al., 1998); $180^{\circ} \mathrm{C}$ for ZHe (Reiners et al., 2002; 2004); $120^{\circ} \mathrm{C}$ for AFT (Gallagher et al., 1998) and $70^{\circ} \mathrm{C}$ for AHe (Wolf et al., 1996; Farley, 2000). B) Lithospherescale cross-section of the Hellenic-Dinaric belt at the latitude of central Albania (modified after Cavazza et al., 2004); I, Ionian; KG, Kruja-Gavrovo; KP, Krasta-Pindos; PK, KorabiPelagonian; S, Sazani-Preapulian; V, Vardar; W, Mirdita.

Fig. 4. Inferred time-temperature histories of samples calculated by inversion of apatite and zicon (U-Th)/He ages (AHe, ZHe), apatite fission-track ages (AFT) and fission-track length 
distributions (FTL) as indicated, using the HeFTy code of Ketcham (2005), for four representative samples from the Internal Albanides. "Age GOF" and "Length GOF" are the goodness-of-fit between the predicted and modelled ages and track-length distributions. Light shaded area in the time/temperature plots represent solutions that provide acceptable fits the observed data (overal GOF $>0.05$ ) whereas dark shaded area shows solutions with good fits $(\mathrm{GOF}>0.5)$; black line is overall "best fit" solution for the samples, for which GOF is reported. Boxes indicate imposed a-priori constraints on thermal history. Thick dashed white line in $(\mathrm{d})$ is the predicted cooling history from a 1D transient thermal model for long-term exhumation of $0.16 \mathrm{~mm} / \mathrm{y}$ punctuated by a pulse of rapid exhumation at $1.2 \mathrm{~mm} / \mathrm{y}$ from $6-4$ Ma. See text for discussion. 


\section{Table Captions}

Table 1. Apatite and zircon (U-Th)/He results for the Albanides. Letters correspond to different crystals of the same sample. $\mathrm{F}_{\mathrm{He}}=$ correction factor for $(\mathrm{U}-\mathrm{Th}) / \mathrm{He}$ age; mwar $=1 / 2$ diameter of the grain; mass $=$ mass of the grain.

Table 2. New apatite fission-track data: $n$, number of counted grains; $\rho_{\mathrm{s}}$, spontaneous track density; $\rho_{\mathrm{i}}$, induced track density; $\rho_{\mathrm{d}}$, dosimeter track density; $\mathrm{N}_{\mathrm{s}}, \mathrm{N}_{\mathrm{i}}, \mathrm{N}_{\mathrm{d}}$, number of tracks counted to determine the reported track densities; $\mathrm{P}\left(\chi^{2}\right)$, chi-square probability that the single grain ages represent one population; D, age dispersion; MTL, mean horizontal confined track length; SD, standard deviation of horizontal confined track-length distribution; No. lengths, number of measured horizontal confined track lengths; $D_{\text {par }}$, mean fission-track etch pit diameter parallel to the crystallographic c-axis for each apatite grain (e.g. Carlson et al. 1999; Donelick et al. 1999). All ages are central ages (Galbraith \& Laslett 1993). Observer: B.

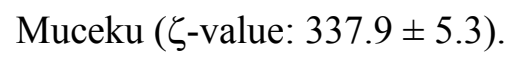




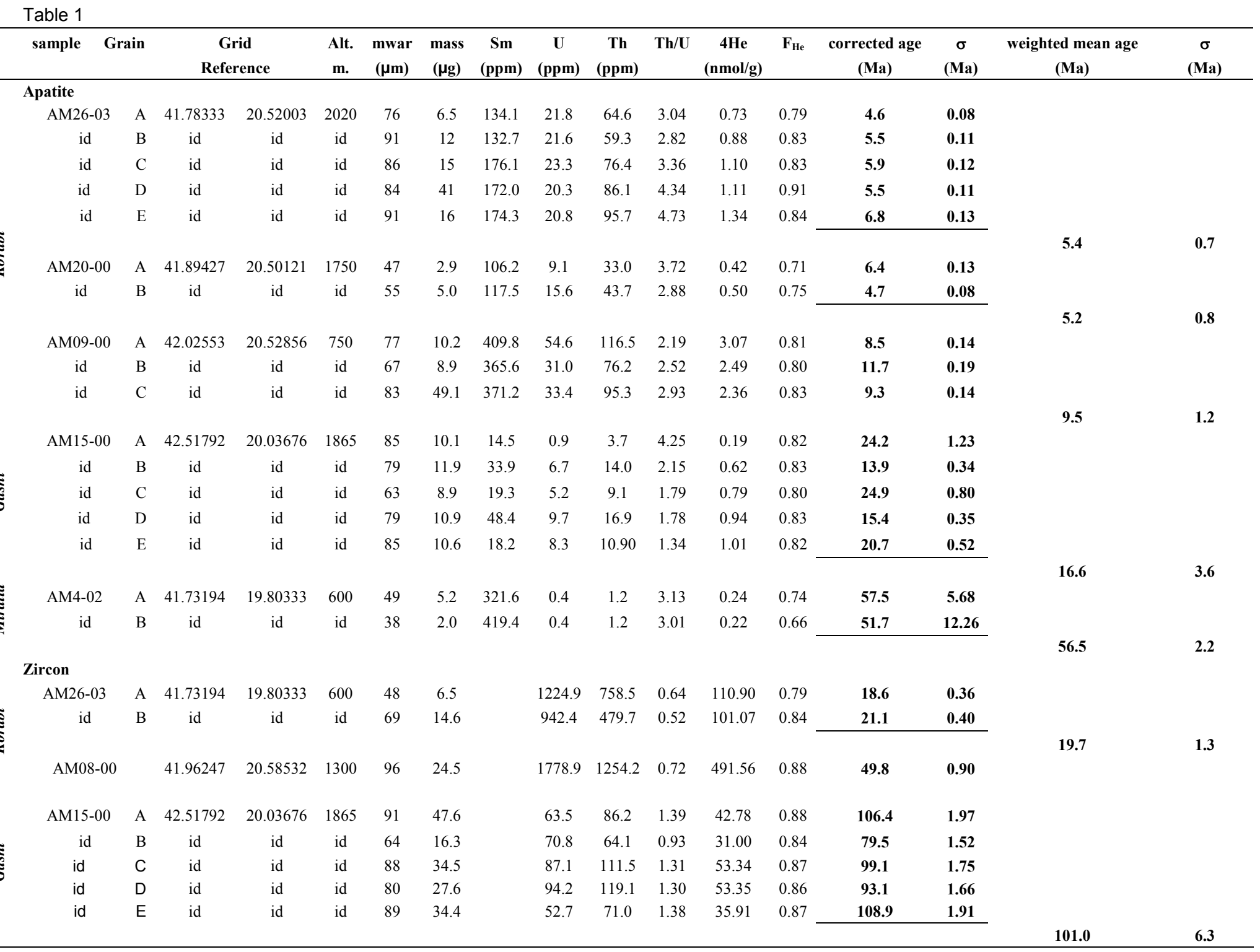




\begin{tabular}{|c|c|c|c|c|c|c|c|c|c|c|c|c|c|c|c|c|c|}
\hline Sample & \multicolumn{2}{|c|}{ Grid } & $\begin{array}{l}\text { Alt. } \\
\text { m. }\end{array}$ & $\mathrm{n}$ & $\begin{array}{c}\rho_{\mathrm{s}} \\
10^{5} \\
/ \mathrm{cm}^{2}\end{array}$ & $\mathrm{~N}_{\mathrm{s}}$ & $\begin{array}{c}\rho_{\mathrm{i}} \\
10^{5} \\
/ \mathrm{cm}^{2}\end{array}$ & $\mathrm{~N}_{\mathrm{i}}$ & $\begin{array}{c}\rho_{\mathrm{d}} \\
10^{5} \\
/ \mathrm{cm}^{2}\end{array}$ & $\mathrm{~N}_{\mathrm{d}}$ & $\begin{array}{c}\mathrm{P}\left(\chi^{2}\right) \\
\%\end{array}$ & $\begin{array}{l}\mathrm{D} \\
\%\end{array}$ & $\begin{array}{c}\text { age } \pm 1 \sigma \\
\mathrm{Ma}\end{array}$ & $\begin{array}{l}\text { MTL } \\
\mu \mathrm{m}\end{array}$ & $\begin{array}{l}\mathrm{SD} \\
\mu \mathrm{m}\end{array}$ & $\begin{array}{c}\text { No } \\
\text { lengths }\end{array}$ & $\mathrm{D}_{\text {par }}$ \\
\hline $\begin{array}{l}\text { AM } \\
4103 \\
\text { AM }\end{array}$ & 42,02550 & 20,58578 & 785 & 21 & 3,15 & (594) & 16,24 & (3061) & 5,345 & (16698) & 97,2 & & $17.5 \pm 0.8$ & 13,01 & 2,9 & 109 & 2,2 \\
\hline 2603 & 41.78333 & 20.52003 & 2020 & 20 & 0,78 & (137) & 7,29 & (1275) & 5,345 & (16698) & $>99$ & & $9.7 \pm 0.9$ & & & & \\
\hline AM 402 & 414355 & 194812 & 600 & 21 & 0,25 & (57) & 0,33 & (75) & 5,411 & (11155) & $>99$ & & $69.1 \pm 12.2$ & & & & \\
\hline
\end{tabular}




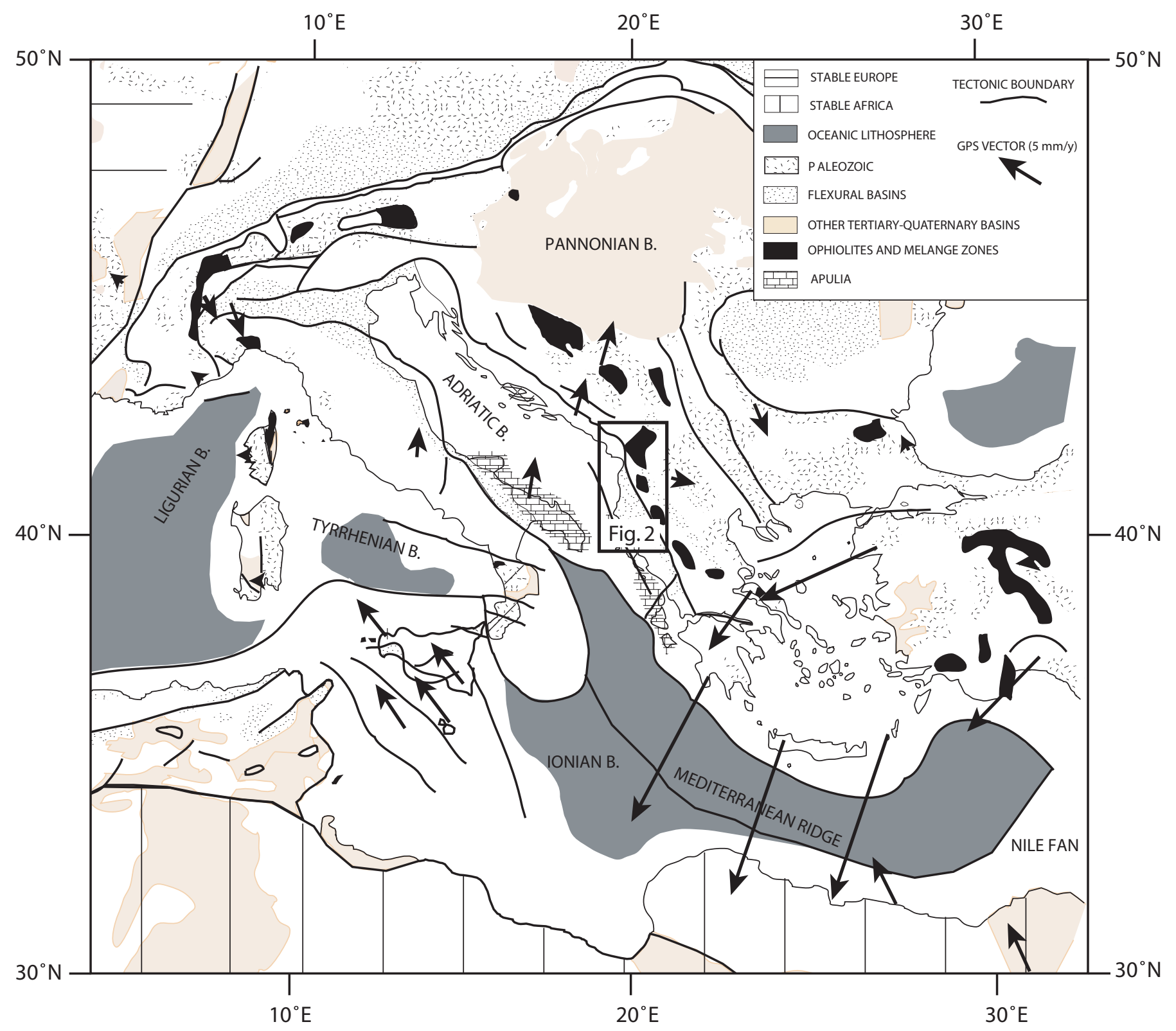

Figure 1:Muceku et al. 


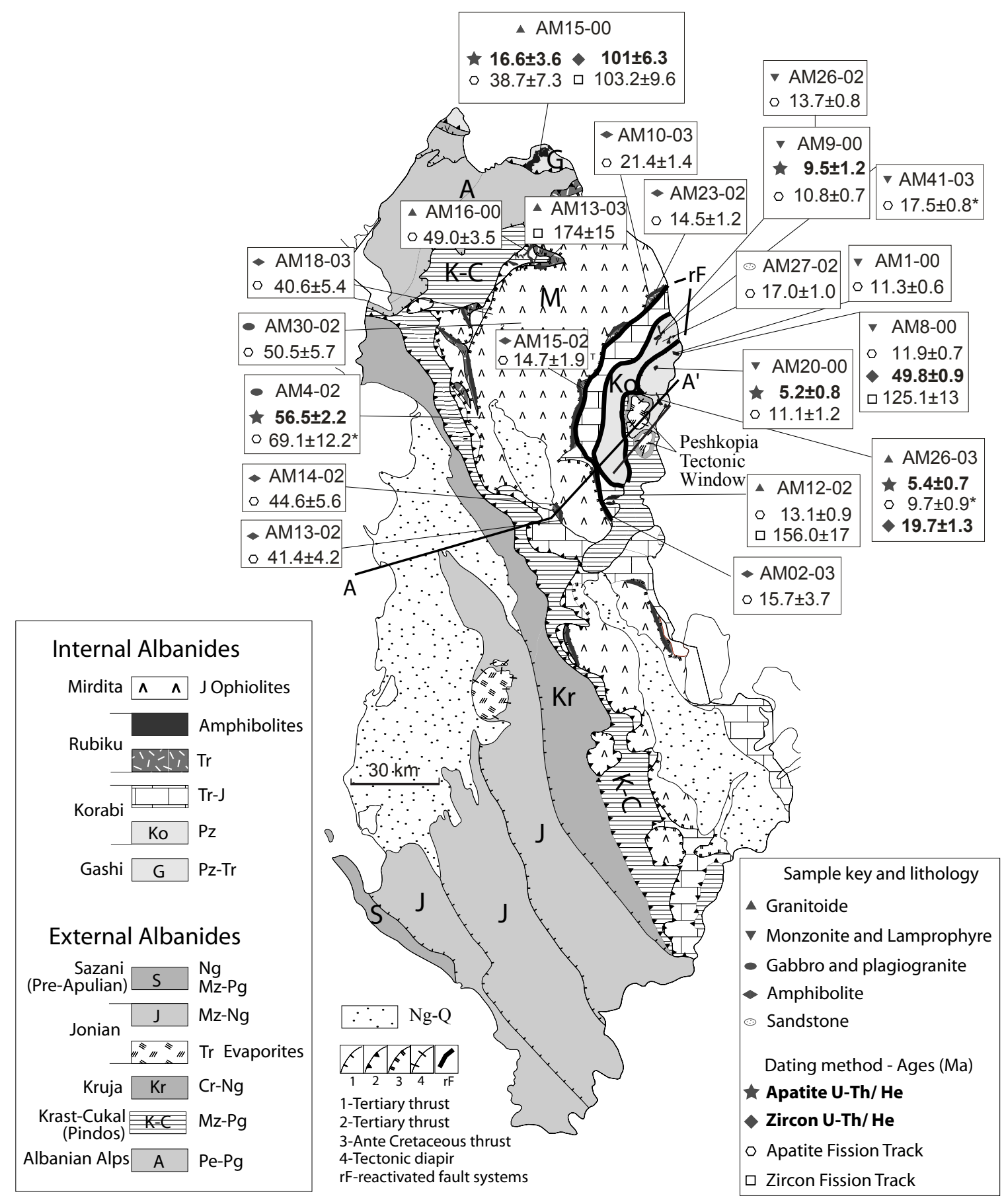

Figure 2: Muceku et al. 
A
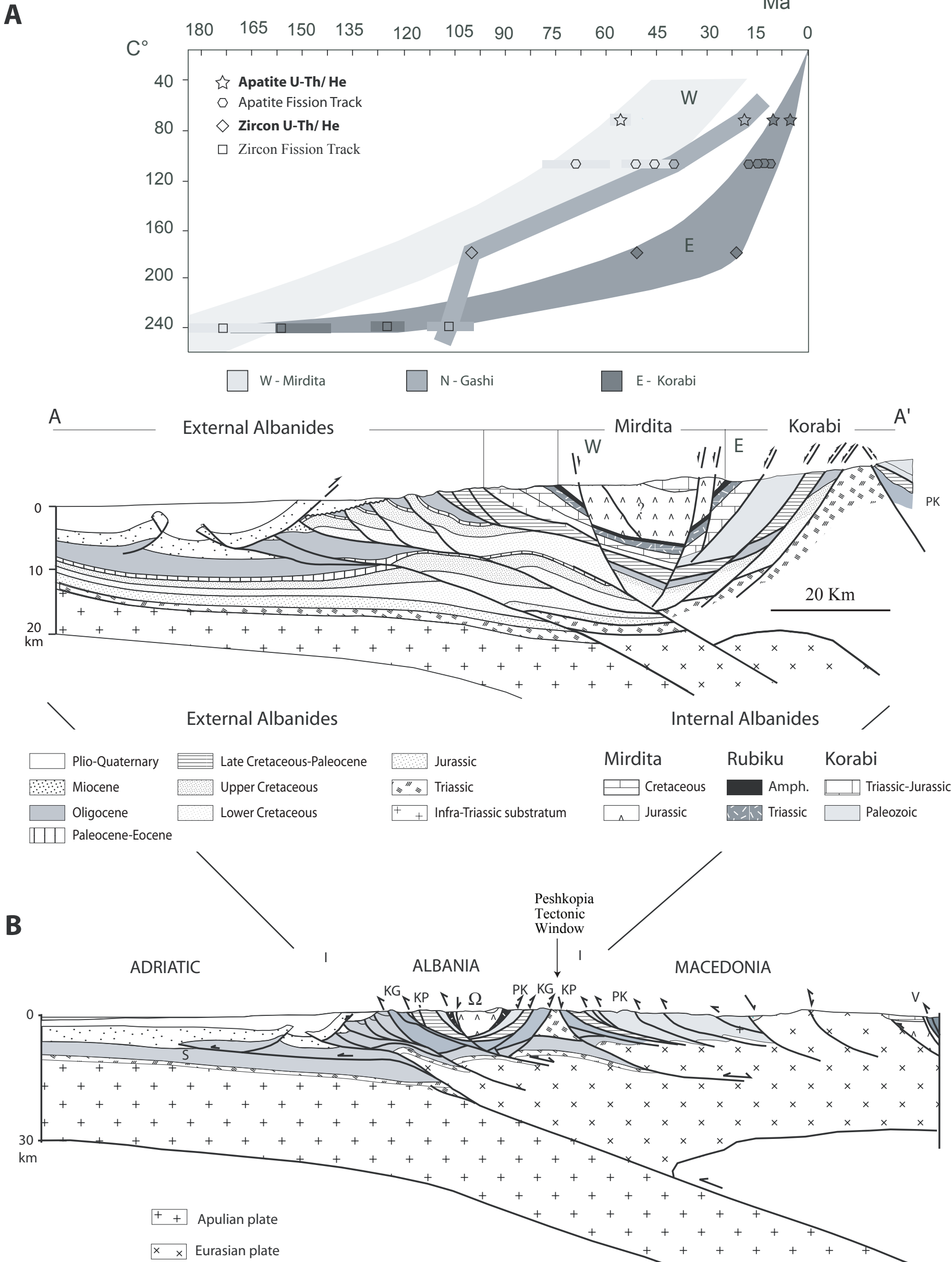

Figure 3 Muceku et al.

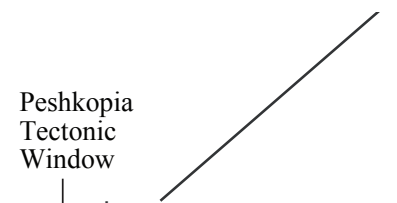

MACEDONIA

\section{ALBANIA}

$\downarrow$

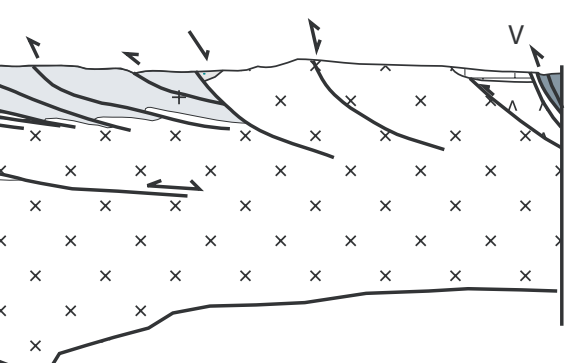



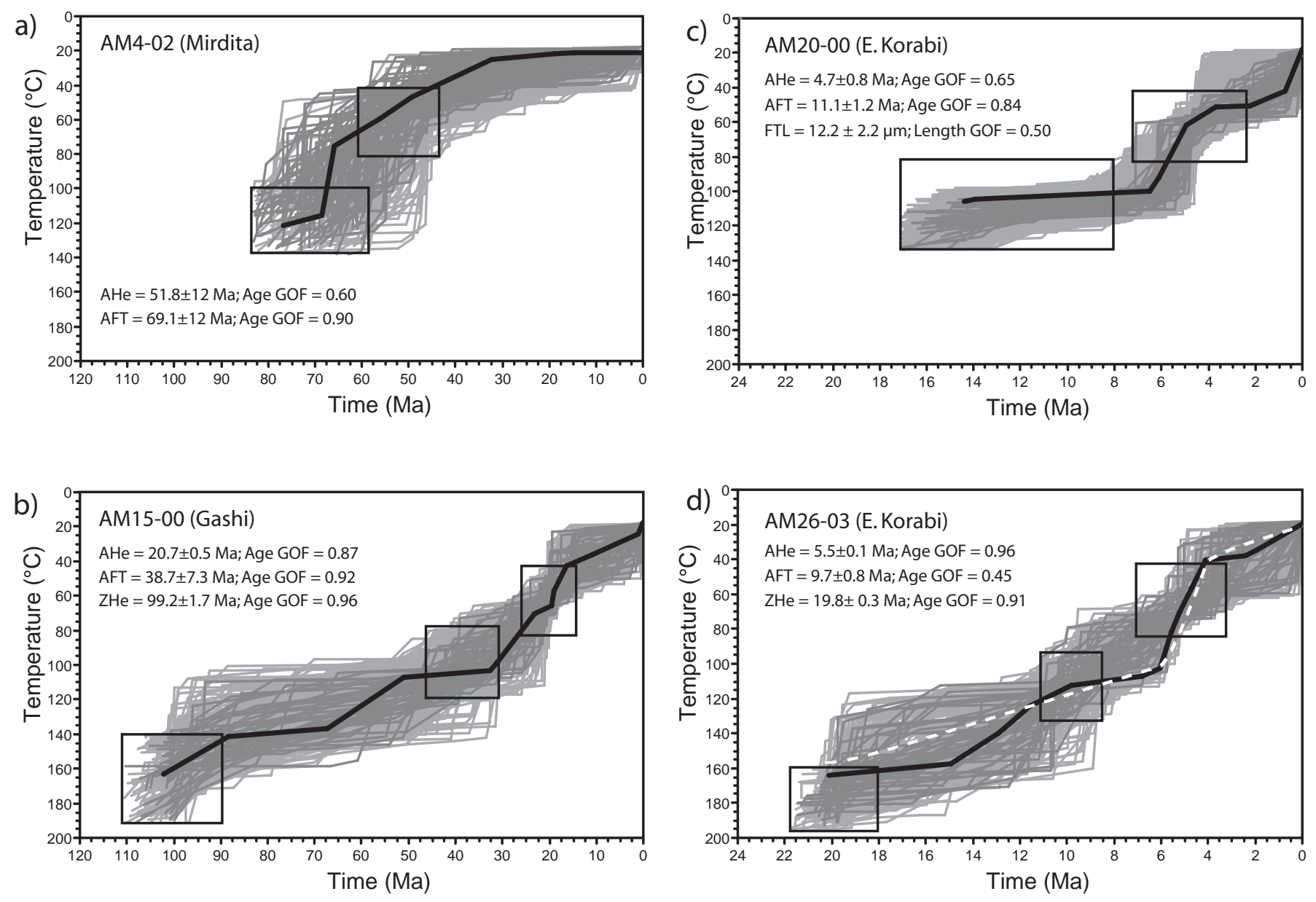

Figure 4 : 